\title{
ОСОБЕННОСТИ ХЕМИЛЮМИНЕСЦЕНТНОЙ АКТИВНОСТИ НЕЙТРОФИЛЬНЫХ ГРАНУЛОЦИТОВ КРОВИ У ПАЦИЕНТОВ С БОЛЕЗНЬЮ ГРЕЙВСА В ДИНАМИКЕ ЛЕЧЕНИЯ РАДИОАКТИВНЫМ ЙОДОМ
}

\author{
Дудина М.А., Фомина Д.В., Догадин С.А., Савченко А.А., Гвоздев И.И., Чанчикова Н.Г. \\ ФГБОУ ВО «Красноярский государственный медичинский университет имени профессора В.Ф. Войно-Ясенецкого» \\ Минздрава России, Красноярск, Россия \\ ФГБНУ Федеральный исследовательский центр «Красноярский научный чентр Сибирского отделения Российской \\ академии наук», обособленное подразделение «НИИ медииинских проблем Севера», Красноярск, Россия \\ ФГБУ «Федеральный Сибирский научно-клинический чентр Федерального медико-биологического агентства», \\ Красноярск, Россия \\ КГБУЗ «Краевая клиническая больнича», Красноярск, Россия
}

ЦЕЛЬ: изучить хемилюминесцентную активность нейтрофильных гранулоцитов периферической крови у больных болезнью Грейвса (БГ) до и через 1 месяц после лечения радиоактивным йодом. МАТЕРИАЛЫ И МЕТОДЫ: В исследование было включено 36 женщин в возрасте от 18 до 65 лет, средний возраст 40,7士13,2, из них 10 (27,7\%) с манифестным гипертиреозом и 26 (72,2\%) с рецидивом заболевания. Определение содержания тиреоидных гормонов осуществлялось методом иммунорадиометрического анализа. Нейтрофильные гранулоциты выделяли из цельной гепаринизированной крови центрифугированием в двойном градиенте

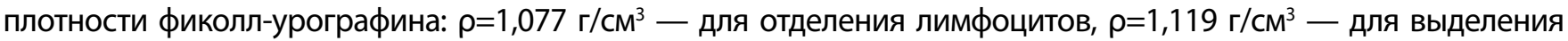
нейтрофилов. Оценку спонтанной и зимозан-индуцированной ХЛ осуществляли в течение 90 минут на 36-канальном хемилюминесцентном анализаторе "БЛМ-3607" (ООО "МедБиоТех", Красноярск). Реактивность нейтрофильных гранулоцитов периферической крови была охарактеризована следующими показателями: время выхода на максимум (Tmax - скорость развития ХЛ реакции), максимальное значение интенсивности (Imax максимальный уровень синтеза активных форм кислорода (АФК)) и площадь под кривой XЛ (S - суммарный синтез АФК за 90 минут измерения). В качестве индикаторов ХЛ реакции использовали люцигенин (реакция светоизлучения только при взаимодействии с супероксид-радикалом) и люминол (реакция светоизлучения при взаимодействии со всеми АФК). Результаты: Медиана уровня ТТГ и свободного тироксина (св. Т4) у обследуемых до РЙТ составила соответственно 0,03 (0,005; 0,54) мЕД/мл и 15,57 (11,42; 20,41) пмоль/л, а содержание Ат рТТГ — $28,01(2,81 ; 35,7)$ МЕ/л. У больных БГ до радиойодтерапии (РЙТ) отмечено снижение Ттах при люцигенин-зависимой ХЛ, как в ходе спонтанной ( $p=0,048)$, так и зимозан-индуцированной реакции $(p<0,001)$. Сниженный до процедуры уровень Imax ( $p=0,038)$ через 1 месяц после РЙТ возрастал ( $p=0,045)$. Это приводит к тому, что суммарный синтез супероксид-радикала, который был повышен у пациентов по сравнению с контролем до проведения РЙт $(p<0,001)$, через 1 месяц после РЙТ возрастает еще значительнее ( $p=0,044)$. При исследовании спонтанной люминол-зависимой ХЛ нейтрофилов у пациентов с БГ до РЙТ при схожих с контролем Tmax и Imax характеризуется значимо большим показателем $\mathrm{S}$ ( $<<0,001)$. При зимозан-индуцированной ХЛ Ттах снижено, в сравнении с контрольной группой $(p=0,033)$, при повышении $\operatorname{Imax}(p=0,004)$ и $S(p<0,001)$. Увеличение показателя $S$ спонтанной и зимозан-индуцированной ХЛ ( $><0,001)$ у больных БГ наблюдалось, как относительно контрольных величин исходно, так и в динамике через 1 месяц после РЙТ. Соотношение Зинд./ऽспонт. люминол-зависимой ХЛ у больных БГ исходно повышено ( $<<0,001)$, через 1 мес. после РЙТ соответствует контрольным величинам.

\section{вЫводы.}

1. У пациентов с БГ выявлены изменения кислородозависимого метаболизма в нейтрофилах периферической крови - увеличение интенсивности образования АФК как при спонтанной ХЛ реакции, так и в нагрузочных тестах.

2. У пациентов с БГ через 1 месяц после РЙТ повышается функциональная активность нейтрофилов.

3. Пациенты с БГ имеют повышенные резервные метаболические возможности нейтрофилов крови, но только на фоне повышения активности, после РЙТ они снижаются.

КЛЮЧЕВЫЕ СЛОВА: болезнь Грейвса; тиреотоксикоз; радиоактивный йод; нейтрофильные гранулоциты; хемилюминесценция; активные формы кислорода. 